\title{
Secure Rights and Non-Credibility: the Paradoxical Dynamics of Canal Irrigation in India
}

\author{
Peter P. Mollinga
}

Department of Development Studies, SOAS University of London, UK

Thornhaugh Street, Russell Square

London WC1H 0XG

UK

pm35@soas.ac.uk.

Peter P.Mollinga completed his Ph.D. on the political economy of unequal water distribution in South Indian canal irrigation in 1998, at Wageningen University, the Netherlands and a Habilitation in Development Sociology at the University of Bonn, Germany in 2008-2009. He is based in the Development Studies department at SOAS since September 2010, and is one of the founding editors of the open access e-journal Water Alternatives (http://www.wateralternatives.org/) 


\title{
Secure Rights and Non-Credibility: the Paradoxical Dynamics of Canal Irrigation in India
}

\author{
This paper contributes to the special issue on institutional Form versus Function \\ by looking at the opposite side of the conceptual equation: clear and formal \\ property rights coupled to low credibility. Since colonial times the formal \\ property rights of the means of agricultural production are clear in South Asian \\ large-scale canal irrigation. However, legal entitlements to water are routinely \\ violated, while canal irrigation exhibits a series of „performance problems ${ }^{c e}$. \\ Legally clearly and securely defined entitlements to water co-exist with unequal \\ distribution in the Tungabhadra Left Bank Canal irrigation system in south India. \\ Neither the formal institutions, nor their insecurity or lack of clarity can explain \\ the existing dynamics and functions of canal irrigation. This lack of analytical \\ purchase derives from both the limitations of property focused theory, and from \\ the inherent characteristics of canal irrigation. Critiques of reductionist \\ approaches have provided a richer conceptual vocabulary, which emphasises the \\ plurality of rights/entitlements as well as that of the causalities at work. Such \\ critiques and the elaboration of alternative frameworks for analysis remain \\ relevant as discourses and practices of „,marketisation of water may be gaining \\ relevance for canal irrigation (reform) in India.
}

Keywords: irrigation; India; property rights; access; reform

\section{Introduction}

British colonial intervention in natural resources management in India can be described as a combination of a long-drawn act of appropriation by dispossession and an extended process of creation of new state and private property rights. For forests, the establishment of the colonial, and independent, state s property claims overfeudal 
This is the accepted version of an article that will be published by Taylor and Francis in Journal of Peasant Studies. Please refer to the published version when citing, available at:

http://www.tandfonline.com/loi/fjps20\#.V5X4yfkrKUk

Accepted Version downloaded from SOAS Research Online: http://eprints.soas.ac.uk/22702/

forest estates and the commons is key; for land the creation of private property through the so called „land settlements ${ }^{e e}$ is the central feature in the colonial period. After India"s independence, the privatisation of land was consolidated and furtherextended. Private property rights in land were introduced in the formerly indirectly ruled parts of the subcontinent, and confirmed in the formerly directly ruled areas, where these had already been established. The land reform process through which this took place was also partially a redistributive reform, involving some dispossession of „landlords ${ }^{e e}$ and redistribution of some of that land to small farmers, tenants and the landless.

While for both forest and land voluminous and rich literatures exist that describe, analyse and assess these changes and reforms (Gadgil and Guha 1992; Aziz and Krishna 1997; Robb 1983), property rights in water have received much less scholarly attention. This is partly due to the fact that water was less the subject of (direct) appropriation and redistribution by the colonial and independent Indian state than forest and land, and therefore less contested. Water appropriation/redistribution remains implicit in land appropriation/redistribution when water rights and access to water are inextricably linked and subordinate to land rights and access to land. This has been predominantly the case in India, at least in state laws, rules and policy frameworks, which construct land rather than water as the primary resource. Land ${ }^{\text {ee }}$ c constructed primacy expresses for instance in the legal arrangement that landowners can freely extract the groundwater under their land, in land ownership (and sometimes tenancy) being a condition for membership of a water users association in government created canal irrigation, and irrigation water fees being levied acre-wise and often collected together with land revenue. There is thus an (implicit) assumption in both colonial and independent state rule that water is not a property object in the same way and with the same status as land. A material condition of possibility for this absence of a,,water 
This is the accepted version of an article that will be published by Taylor and Francis in Journal of Peasant Studies. Please refer to the published version when citing, available at:

http://www.tandfonline.com/loi/fjps20\#.V5X4yfkrKUk

Accepted Version downloaded from SOAS Research Online: http://eprints.soas.ac.uk/22702/

rights $^{e e}$ discourse as regards agricultural water use, was that surface water was on average, in between the scarcities of droughts and the excesses of floods, seemingly abundant, and could be diverted apparently without competing with other uses. ${ }^{1}$

This situation is changing. In the $21^{\text {st }}$ century basins are closing and aquifers suffer over-extraction, while the ecological uses of water are at least acknowledged. ${ }^{2}$ Water scarcity discourses gain force as a result, with, in mainstream economic perspectives, calls attached for valuing water at its ,true ${ }^{e e}$ price, for the introduction of water markets, and with implicit or explicit arguments for individual property rights in water. In groundwater use for irrigation water markets have emerged, notably as part of the tubewell boom that started from the 1970s (Shah 2009, 37: Figure 2.1).

Groundwater markets have been promoted as an instrument for poverty alleviation (Shah and Raju 1988) a position that has been strongly contested (Dubash 2002; Prakash 2005; Janakarajan and Moench 2006). In surface water use for irrigation, the focus of this paper, ideas on water markets and individual property rights in water have made much less advance, practically as well as discursively, but also in this respect times may be changing. Given the force of (neo)liberalisation, it seems plausible that advocacy for policy to move further into the „marketisation ${ }^{\text {ee }}$ direction will gain in strength. Consideration of the property object status of water is thus not only relevant

1 In colonial times there was little focus on groundwater in state policy and the reference is therefore to the ,harnessing ${ }^{\text {ee }}$ of surface water for that period. It is relevant to note that in India more than $90 \%$ of diverted surface water and extracted groundwater is used for agricultural purposes, i.e. irrigation (data available at the FAOSTAT website of theFood and Agriculture Organisation).

${ }^{2}$ For example through the Wetlands (Conservation and Management) Rules 2010 passedunder the Environment Protection Act, 1986. 
This is the accepted version of an article that will be published by Taylor and Francis in Journal of Peasant Studies. Please refer to the published version when citing, available at:

http://www.tandfonline.com/loi/fjps20\#.V5X4yfkrKUk

Accepted Version downloaded from SOAS Research Online: http://eprints.soas.ac.uk/22702/

for the intellectual purposes of this special issue, but also for practical Indian policy reasons.

As suggested above, no private property rights in surface water for canal irrigation exist in India in a way comparable with land as private property. However, there are, as will be shown, clearly defined legal entitlements to water for individual canal irrigators. These are not generally talked about as ,rights ${ }^{\text {ee }}$, but they have been treated as such by individual irrigators in certain circumstances and periods.

Despite the clear and legal status of these entitlements they have, at present, little practical relevance for actually existing canal water distribution. Canal irrigation infrastructure has been designed technically to reflect these entitlements, and in that sense sets physical boundary conditions (notably canal capacities) for water distribution. However, the operational rules (cf. Ostrom 1990) for that distribution have emerged, over time, in repeated seasonal and yearly cycles of distribution practices, quite independently from the formal legal rule set. These rules reproduce patterns of unequal water distribution, and co-exist with other canal irrigation „performance problems ${ }^{\text {ee }}$ like yield gaps (agricultural productivity below potential) and poor cost recovery (water fee collection rates between 2 and 8\% (PC/GOI 2013:151) make canal irrigation a heavily subsidised sector).

This situation raises a number of questions relevant to the theme of this special issue.

1. Why do the legally defined entitlements to canal water for individual irrigators not carry more weight in practice? It will be shown that this is not due to lack of clarity or fuzziness of their legal status, but to systemic characteristics of Indian governance and politics as these have developed post-independence. 
This is the accepted version of an article that will be published by Taylor and Francis in Journal of Peasant Studies. Please refer to the published version when citing, available at:

http://www.tandfonline.com/loi/fjps20\#.V5X4yfkrKUk

Accepted Version downloaded from SOAS Research Online: http://eprints.soas.ac.uk/22702/

2. What is the status and degree of institutionalisation of actually existing rules for water distribution at different levels of the irrigation system? It will be shown that elaborate, institutionalised systems of rules exist at the three system levels of local irrigation units, secondary canals and the main canal. This supports Ribot andPeluso ${ }^{\text {ee }} \mathrm{s}$ (2003) argument that in addition to a theory of (property) rights, a theory of access is required, because (property) rights do not automatically translate into access, and are not the only route towards access.

3. Is the situation of unequal water distribution and other ,performance problems" in Indian canal irrigation due to the fact that the legal entitlements to water have not been defined as individual property rights? That is, could recasting of entitlements as (individual) property rights help to enhance the performance of canal irrigation - as mainstream economic theory tends to suggest? The answer to this third question must be largely conjectural as there is no example in India to test this empirically, and extremely few examples in other developing countries ${ }^{\text {ee }}$ canalirrigation either. The paper argues that it is highly unlikely that a policy shift towards defining water property rights will make a positive contribution to enhancing canal irrigation performance. If anything, the contrary is more plausible.

The broader theoretical issue these findings and considerations raise is that of the appropriate terminology for capturing the complexity and meaning of the institutional arrangements in canal irrigation that shape access to water: rights, property, entitlements - what analytical and explanatory power do these concepts carry? The paper argues that imposing categorical definitions and typologies on specific situations is not particularly helpful. The meaning of generic concepts like property, rights, and entitlements is contextual. The unravelling of that contextuality is exactly what gives 
This is the accepted version of an article that will be published by Taylor and Francis in Journal of Peasant Studies. Please refer to the published version when citing, available at:

http://www.tandfonline.com/loi/fjps20\#.V5X4yfkrKUk

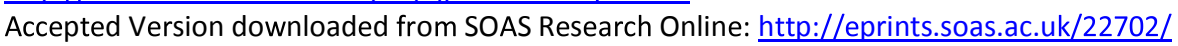

insight into the broader cultural political economy that canal irrigation is part of and that it helps to reproduce. Unravelling function beats remaining stuck in form.

The more detailed discussion of these issues proceeds as follows. Section 2 discusses property rights arrangements in Indian irrigation and associated strategies for water allocation in general. The paper takes the Tungabhadra Left Bank Canal (LBC) irrigation system in Karnataka, south India, as the main case example, because it represents the „,clearest ${ }^{\mathrm{e}}$ form of water entitlement definition.. Section 3 presents the actually existing access relations in the Tungabhadra LBC example, outlines the rule systems that have emerged in response to the operational inefficacy of formal entitlements, and discusses the function and credibility (Ho 2013, 2014) of the rules and the social relations in which water distribution is embedded. It also provides reflections on the need for a theory of access and the contextuality of law.

These two sections provide answers to questions 1 and 2 listed above. The third question is addressed in section 4. It discusses the purchase of property-rights focused economic theory for understanding canal irrigation dynamics. Three critiques are elaborated. These address the basic assumption that private property based market can effectively perform allocative and efficiency enhancing tasks, the reductionism of (neoinstitutionalist) economics and other disciplinarily focused explanations, and the inherent characteristics of canal irrigation as inhibiting ,,marketisation ${ }^{\text {ee }}$ Section 5 concludes with a reflection on the property object status of water in (Indian) canal irrigation.

\section{Property rights and allocation in protective irrigation}

Colonial construction of large-scale irrigation started mid- $19^{\text {th }}$ century, in the Indo- 
This is the accepted version of an article that will be published by Taylor and Francis in Journal of Peasant Studies. Please refer to the published version when citing, available at:

http://www.tandfonline.com/loi/fjps20\#.V5X4yfkrKUk

Accepted Version downloaded from SOAS Research Online: http://eprints.soas.ac.uk/22702/

Gangetic plains in the north, and in the deltas in the south (Whitcombe 1972; Stone 1984; Wallach 1985). It gained further momentum in response to the famines of the second part of the $19^{\text {th }}$ century (Famine Commission 1880, 1881, 1898). Public Works Departments and Engineering Colleges were established in this period - canal irrigation professionalised. The Report of the Indian Irrigation Commission 1901-03 is a landmark document as regards the establishment of colonial irrigation policy. By the end of the colonial era 13.57 million ha of canal irrigation had been constructed (Mollinga 2003, 59; GOI/MOIP 1972, 261).

The property rights situation with regard to surface water that emerged out of the colonial process is one where the state is formally the owner of all surface water resources, and the chief allocator of it (Upadhyay 2009; see also Cullet 2009, 40-1). In India, river flows are allocated by the state for different uses in yearly quantitative volumes, with the allocations having a long-term validity of several decades. ${ }^{3}$ For example, the Tungabhadra Left Bank Canal irrigation system that is the main case example of this paper has a yearly allocation of 100 TMCft (thousand million cubic feet) under the Krishna river ,,award ${ }^{e e}$ (the Tungabhadra being a tributary of Krishna). ${ }^{4}$ The (colonial and independent) statee s assumption of the overall ownership of the natural resource water meant that it could assume the role of a developmental state. It vested the authority in itself to implement large scale infrastructural works to re-arrange

3 For example, the 1972 Krishna river award (GOI/KWDT 1973) had a duration of 25 years. As revision is a lengthy, because contested, process, which can take decades, allocations remain stable for very long periods. The legal process for agreeing and reviewing such awards is the 1957 Water Disputes Tribunal Act.

4 Available water in rivers is calculated based on a „dependable flow“e. For the Krishna river this was a $75 \%$ dependable flow, meaning that the allocation would on average be physically available in three out of four years. 
This is the accepted version of an article that will be published by Taylor and Francis in Journal of Peasant Studies. Please refer to the published version when citing, available at:

http://www.tandfonline.com/loi/fjps20\#.V5X4yfkrKUk

Accepted Version downloaded from SOAS Research Online: http://eprints.soas.ac.uk/22702/

the availability of surface water in time and space by the construction of weirs, dams, canals and other infrastructure. ${ }^{5}$ The landmark document for independent irrigation policy is the Report of the Irrigation Commission (GOI/MOIP 1972). Policy focus in recent decades has shifted to groundwater irrigation and to urban and industrial water supply, as is clearly visible in the recent XIIth Five Year Plan document (PC/GOI 2013). Nevertheless, budget allocations for large-scale canal irrigation have remained relatively stable since 1990 as a percentage of Plan expenditure. ${ }^{6}$ The present extent of Indian large-scale canal irrigation is officially reported as 47.41 million ha (potential created) and 35.01 million ha (utilised) at the end on the XIth Plan 2007-2012 (PC/GOI 2013, 183). ${ }^{7}$

Much of the canal irrigation constructed is located in the dry, semi-arid regions of India, and always exposed to an erratic monsoon rainfall regime of only a few months per year. The Tungabhadra Left Bank Canal exemplifies such a system. It is located in north Karnataka, a region with 500-600 mm average, but highly variable,

5 The authority assumed not only speaks from the power to allocate water, but also from the power to acquire land for these construction purposes, that is, to dispossess citizens for the benefit of overall development (see the Land Acquisition Act, 1894, recently replaced by the Right to Fair Compensation and Transparency in Land Acquisition, Rehabilitation and Resettlement Act, 2013).

6 Between 1990 and 2012 Government of India expenditure for major and medium irrigation varied between 4.4 and 5.2 \% (no trend) of total Plan expenditure. Between 1956 and 1990 it varied between 6.5 and $9.4 \%$, the peak being the period 1974-1980 (calculated from Annexure 5.1, PC/GOI 2013, 181)

7 These figures refer to the category „major and medium irrigation “. Groundwater irrigation area stands at 41.82 million ha. 
This is the accepted version of an article that will be published by Taylor and Francis in Journal of Peasant Studies. Please refer to the published version when citing, available at:

http://www.tandfonline.com/loi/fjps20\#.V5X4yfkrKUk

Accepted Version downloaded from SOAS Research Online: http://eprints.soas.ac.uk/22702/

rainfall per year. It was a famine region in the colonial period, which was a major reason for considering the construction of the irrigation system. ${ }^{8}$

Within the bulk, yearly, quantitative allocations that each system receives, water for canal irrigation is further allocated to individual water users, or occasionally to groups of these. It is even allocated for irrigation of particular pieces of land, during particular times (seasons), with particular volumes of water or time-shares of available flow. This allocation, and the related distribution, has been designed in regionally varying ways. In the semi-arid, relatively water scarce regions of India the colonial period produced a threefold regional variation (Wade 1976; Jurriëns and Mollinga 1996):

(1) the warabandi system in the north (notably present day Haryana, Punjab and Uttar Pradesh),

(2) the block system in the west (notably present day Maharashtra), and

(3) the localisation system (present day Karnataka, Andhra Pradesh and Tamil Nadu).

These allocation systems defined entitlements to irrigation water in different ways. The northern warabandi system worked on a time-share basis, allocating hours+minutes of available flow per unit area of irrigable land, with farmers free to choose their crops (Malhotra 1982; Narain 2003). The western block system attempted to introduce measured volumetric supply to groups of farmers cultivating „blocks ${ }^{\text {ee }}$ with one-third high water consuming sugarcane as a cash crop, and two-thirds low water

8 On the long drawn, 1860-1940s, negotiation on the decision to construct and the technical design of the system, see Mollinga (2003, chapter 4). 
This is the accepted version of an article that will be published by Taylor and Francis in Journal of Peasant Studies. Please refer to the published version when citing, available at:

http://www.tandfonline.com/loi/fjps20\#.V5X4yfkrKUk

Accepted Version downloaded from SOAS Research Online: http://eprints.soas.ac.uk/22702/

consuming food and fodder crops (Bolding et al. 1995). The southern localisation system was the most strongly prescriptive variant of allocation. It prescribed for each irrigable cadastral unit which crop could be grown in which season, and how much water was to be supplied for that (Mollinga 2003).

\section{The rationing challenge}

Common to the three systems is that they involve the demarcation of land that is allowed to be irrigated (and thus, simultaneously, land that is excluded from irrigation), and allocation of water in relation to the size of the holding, showing the connection of water rights/entitlements to land. All three allocation systems have as their main characteristic and challenge that they ration water. In the so called protective irrigation systems that were constructed in the low rainfall regions, farmers are not entitled for irrigation of full crop water requirements (which would maximise the crop ${ }^{\text {ee }}$ s yield), but they are allocated a part of these full-growth requirements for supplementary irrigation. Protective irrigation systems aim to spread water thinly over large areas and numbers of farmers, supplying only part of the total water needs of crops. This is in contrast to systems that supply full crop water requirements - examples of this being the delta and some river systems built in South India in the colonial period for rice cultivation. ${ }^{9}$ Protective irrigation, in theory, protects crops against failure, farmers against famine/poverty and optimises overall (rather than individual) output (maximising,,crop per drop ${ }^{e e}{ }^{10}$

9 For the concepts of protective and productive irrigation, see Mollinga (2003, chapter 3). 10 For the economics of this, see Mitra (1986), Rath and Mitra (1989) and Dhawan (1988, 1989). The 1972 Irrigation Commission wrote: “In areas other than those with ample 
This is the accepted version of an article that will be published by Taylor and Francis in Journal of Peasant Studies. Please refer to the published version when citing, available at:

http://www.tandfonline.com/loi/fjps20\#.V5X4yfkrKUk

Accepted Version downloaded from SOAS Research Online: http://eprints.soas.ac.uk/22702/

The rationing requirement that characterises protective irrigation, is technically expressed in a decision on what the „duty ${ }^{\text {ee }}$ of irrigation is, meaning the number of acres that can be irrigated with a unit flow (usually expressed in acres/cusec ${ }^{11}$ ). A low duty means a lot of water per unit of land; a high duty means less water per unit of land. ${ }^{12}$ In protective irrigation, duties are set in such a way that they imply supplementary irrigation rather than irrigation to full crop requirements, thus rationing water. In the northern warabandi system this was achieved by allocating time shares in combination with certain canal flows without prescription of crops. In the western block system and southern localisation systems design, quantities of water are combined with the prescription of crops (or more precisely, the prohibition of high water consuming crops on most of the irrigable land). Localisation is the most detailed and most strongly prescriptive of these. The list of cadastral units (called survey numbers in India) with

water resources (...) our policy should aim at securing the maximum crop production per unit of water. (...) the policy should be to benefit as large a section of the community as possible and at the same time enable farmers to obtain reasonable yields. Surface irrigation systems should be designed to irrigate compact blocks, the blocks being dispersed over a large area to benefit large numbers of farmers. The number of irrigations can be fewer than are required for high yields.” (GOI/MOIP 1972, 112-3).

11 An acre is 0.405 hectare, with a hectare measuring $10,000 \mathrm{~m}^{2}$. A cubic foot is $(0.305 \mathrm{~m})^{3}$ or $0.0283 \mathrm{~m}^{3}$ (and a cusec therefore $28.3 \mathrm{l} / \mathrm{sec}$ ). The Tungabhadra LBC yearly allocation of 100 TMCft thus equals $100 \times 1000 \times 10^{6}$ x $0.0283 \mathrm{~m}^{3}$, or $2.83 \mathrm{~km}^{3}$.

12 Duty is the inverse of water allowance, which is usually expressed in liter/second.ha. Water allowance is the continuous flow (liter/second) to a unit size of land (hectare) over the length of the growing season. High allowance means a lot of water on the plot; low allowance means little water on the plot. 
This is the accepted version of an article that will be published by Taylor and Francis in Journal of Peasant Studies. Please refer to the published version when citing, available at:

http://www.tandfonline.com/loi/fjps20\#.V5X4yfkrKUk

Accepted Version downloaded from SOAS Research Online: http://eprints.soas.ac.uk/22702/

crop and season specification was published in the State Gazette for the case of the Tungabhadra Left Bank Canal. ${ }^{13}$

Localisation can thus be regarded as the creation of clear and specific

entitlements to canal irrigation water, specified for land units, seasons and in total quantity of water to be received, and with a clear legal status. Under the Karnataka Irrigation Act, 1965 two offences were defined: violation of cropping pattern (VCP, meaning the growing of unauthorised crops) and unauthorised irrigation (UI, irrigation of land outside the prescribed/allowed area or season) (under sections 28(5) and 32(4)). Fines were attached to both, which to this day are administered and calculated in long lists of survey numbers per village for every irrigation season. Also, canal water release schedules are to this day calculated based on the localisation schedule (that is, the assumed areas and crops inform the water flows to be released into different canals (and originally, in the design and building phase, informed the dimensions of the canals as such).

In all three regions mentioned, the practice of distribution differs substantially from the formal rationing schedule. The basic issue is that the logic of the collective optimum contradicts the logic of the individual optimum. While rationing water may maximise overall production and reduce risk for the largest number of people, and increase their livelihood security, for an individual farmer it makes sense to appropriate additional water for higher yields in more than one season. The one-season water use of an „irrigated dry ${ }^{e e}$ crop as prescribed in the Tungabhadra LBC localisation scheme, and the two seasons of wet rice farming that farmers practice when they get a chance, differ

13 Details of the features of localisation and irrigation system design are discussed in Mollinga (2003). The 1956 Localisation Rules under which the Tungabhadra localisation was done are reprinted there. 
This is the accepted version of an article that will be published by Taylor and Francis in Journal of Peasant Studies. Please refer to the published version when citing, available at:

http://www.tandfonline.com/loi/fjps20\#.V5X4yfkrKUk

Accepted Version downloaded from SOAS Research Online: http://eprints.soas.ac.uk/22702/

in total water use with a factor of four to five. This ratio immediately suggests that in case two-season rice cultivation becomes prevalent, the resulting deprivation of other entitlement holders will be dramatic, resulting in highly skewed water distribution and large parts of the potentially irrigable area not receiving any irrigation water. Such appropriation of excess water (as compared to formal entitlement) for two-season rice cultivation happened on a large scale in the Tungabhadra system. The region became a major rice producing region in Karnataka. ${ }^{14}$

The resulting skewed distribution is the classical „head-tail ${ }^{\text {ee }}$ pattern of unequal water distribution that is found in much canal irrigation, in India as elsewhere, and which is central to irrigation policy reform debates. The causes of the unequal distribution have been analysed differently, ranging from technical deficiency of the infrastructure (leaking canals and deferred maintenance), to locational advantage, to more complex institutional and political economy explanations (Chambers 1988; Suhardiman and Mollinga 2012). The seemingly chaotic process in which unequal water distribution is produced has been characterised by some as a „syndrome of anarchy"e (Hart 1978; Lowdermilk 1990) - implying the absence of a rule-based logic. Though unequal distribution in the Tungabhadra LBC is no doubt a dramatic process (involving manipulation of outlet gates and canal blockages, guarding of outlets in peak

14 It is outside the scope of this paper to discuss in detail the way this appropriation of irrigation water for rice cultivation unfolded from the opening of the main canal in 1953. It was not only the result of individual farmer choice, but also of government policy in the early decades of the canale ${ }^{e s}$ existence to use available water for maximum foodproduction, India being short of food in the 1960s-1970s. With the reservoir construction completed in 1953 but the canal system only completed in 1968, there was a long period of high water availability as against irrigable land, establishing a logic of allowing intensification for maximising food production. 
This is the accepted version of an article that will be published by Taylor and Francis in Journal of Peasant Studies. Please refer to the published version when citing, available at:

http://www.tandfonline.com/loi/fjps20\#.V5X4yfkrKUk

Accepted Version downloaded from SOAS Research Online: http://eprints.soas.ac.uk/22702/

season to avoid such manipulation, petitions and lobbying, road blockades,

demonstrations and sit-ins, and several other things), that drama is structured by,

sometimes highly sophisticated, rules. Water distribution rules exist at three levels, which I discuss in the next section.

\section{Access relations in the Tungabhadra LBC}

In this section I discuss the rules that have been designed, over time, for daily water distribution in the Tungabhadra LBC, in response to the inefficacy of the localisation schedule. The three levels of rules are those at the level of the local irrigation unit, those at the level of the secondary canals (the canals that link the main canal that takes water from the Tungabhadra reservoir with the local irrigation units), and those at the level of the main canal. The descriptions are brief, for details see Mollinga (2003, chapters 6, 7 and 9). The description is followed by a presentation of the structure of social relations that underpins unequal water distribution.

\subsection{Farmer designed rotation schedules in local units}

Local irrigation units are areas of roughly 50 to 150 acres (20 to 60 hectares) in size, in which several tens of farmers have land. Such a unit receives water from the government managed canal system through an „outlet ${ }^{\text {ee }}$, a structure with a pipe that can be closed with a steel gate. Government managers have no formal responsibility „,below the outlete; this is the domain where farmers distribute water among themselves, making use of field channels that convey water from the outlet structure to individual plots. The distribution among (unequally sized) plots takes place in sequence, that is, plots are irrigated with the available flow in turns. Irrigation of plots in turns with concentrated 
This is the accepted version of an article that will be published by Taylor and Francis in Journal of Peasant Studies. Please refer to the published version when citing, available at:

http://www.tandfonline.com/loi/fjps20\#.V5X4yfkrKUk

Accepted Version downloaded from SOAS Research Online: http://eprints.soas.ac.uk/22702/

flow reduces irrigation time per plot and seepage losses in the field channels as compared to a situation where several plots are irrigated simultaneously. The so called rotation schedules usually employ the seven day week as the unit of rotation, and specify the timing and duration of the irrigation of each plot in that week. Almost without exception the allocation of time slots is relative to the size of the plot. For example, in a 42 hectares sized local unit, each hectare would be entitled to receive four hours of the full flow per week (as a week counts 168 hours). Outlet areas are usually divided in zones, and sequences for plot irrigation fixed within these zones. Beyond these general principles, rotation schedules vary considerably in their detail across different local units. They may or may not include alternation of day and night irrigation across weeks, months or seasons, and reversals of plot irrigation sequences. All have been designed by farmers in response to the specificities of water scarcity occurrence in their unit. One important variation relates to the predictability and size of the flow received from the government canal system. In outlet areas whose supply varies systematically over the week (say three days with high supply, four days with low supply as a result of higher level rotation schedules), the time/ha allocation may be different for these two periods. Field research revealed examples of outlet areas with a different time/ha allocation for each day of the week, as a fine tuning to varying supplies. A common feature of all rule systems was that they functioned as resources mobilised when necessary. When water scarcity/demand reaches a level that irrigation sequencing can no longer be arranged informally without conflict, the rule system is called upon.

The sophistication and flexibility of outlet area level rule systems for the rotation of irrigation, and the seemingly equitable design principle of time/ha, do not imply the absence of unequal distribution. In fact, unequal distribution, mostly in a 
This is the accepted version of an article that will be published by Taylor and Francis in Journal of Peasant Studies. Please refer to the published version when citing, available at:

http://www.tandfonline.com/loi/fjps20\#.V5X4yfkrKUk

Accepted Version downloaded from SOAS Research Online: http://eprints.soas.ac.uk/22702/

head-tail pattern, was the general observation in the areas and seasons with insufficient water for $100 \%$ rice cultivation. The basic mechanism explaining this paradox (of equity based rules with unequal outcomes) was located in the planting of low-water consuming crops by small farmers in anticipation of losing water distribution conflicts with large farmers in peak demand periods (for dependency relations between the two classes of farmers see below). Water conflicts where thus displaced to crop choice, with the more water consuming crops being the more remunerative crops.

\subsection{Government-elite farmers negotiated rules at secondary canal level}

Local irrigation units are situated along secondary canals, in a queue from the upstream side, where water enters the secondary canal from the main (or primary) canal, till the downstream end, where the secondary canal usually empties in a natural drain. Secondary canals are formally managed by the irrigation agency and farmers are supposed not to be involved in the delivery of water through local unit outlets. However, the secondary canals are a main site of farmer activity ,,above the outlet". A key aspect of water access is securing a regular and sufficient supply to one $e^{\text {ee }}$ local unit. For this purpose local unit groups have organised for „external action ${ }^{\text {ee }}$ in order to secure such supply. This involves collection of money (often area-wise) to cover costs for lobbying the irrigation agency officials and local politicians, the employment of labour to guard outlets along the canal in peak periods of water demand (to control excess appropriation upstream and to avoid blocking by downstream farmers of one ew $^{\text {ewn }}$ outlet gate), and to appoint larger, well-placed and capable farmers as outlet representatives, for engaging in day-to-day water distribution conflicts along the secondary canal as well as for interacting with officials and politicians in their offices 
This is the accepted version of an article that will be published by Taylor and Francis in Journal of Peasant Studies. Please refer to the published version when citing, available at:

http://www.tandfonline.com/loi/fjps20\#.V5X4yfkrKUk

Accepted Version downloaded from SOAS Research Online: http://eprints.soas.ac.uk/22702/

and homes. A secondary canal has a length of several to several tens of kilometres, and there are thus many outlets competing for water in water scarce periods. In response to this, elite farmers and government managers have negotiated rotation schedules over local irrigation units, for example by dividing the canal in sections, with each section getting preferential supply for specific days of the week. The variation in the detail of this is considerable, given very different canal lengths, bifurcation patterns, and the spatial distribution of the differential socio-economic power of local units and villages. Implementation of the rotation schedules, often formally announced by the irrigation agency and printed on pamphlets, and mobilised in peak periods of demand when informal mediation no longer works, in principle happens by the irrigation agency staff, particularly during the day. At night farmers ,implement ${ }^{e c}$ by manipulating and guarding outlet gates. When conflicts escalate, the irrigation agency also undertakes night guarding activities by patrolling the canal. The schedules negotiated between the agency and the local leadership of elite farmers consolidate a pattern of unequal head to tail distribution, in which there is some balance found between efforts to push water as far down the canal as possible and local power equations. They are an institutional tool for arranging a somewhat predictable water supply schedule in water scarce periods ${ }^{15}$.

\subsection{Internal rules in the irrigation agency at main canal level}

The main (primary) canal that takes water from the reservoir created by the

15 Fieldwork in 2015 confirmed that these rotation schedules at secondary level continue to be in place, with pamphlets printed. However, it was also found that the number of Irrigation Department staff posted at canal level has gone down considerably over the preceding decade. This may mean that government patrolling and related activities have become less frequent and effective over time. 
This is the accepted version of an article that will be published by Taylor and Francis in Journal of Peasant Studies. Please refer to the published version when citing, available at:

http://www.tandfonline.com/loi/fjps20\#.V5X4yfkrKUk

Accepted Version downloaded from SOAS Research Online: http://eprints.soas.ac.uk/22702/

Tungabhadra dam to the offtakes of the secondary canals is more than $200 \mathrm{~km}$ long, and is managed by four irrigation agency divisions, each headed by an Executive Engineer.

There are in total more than 80 secondary canals drawing water from the main canal, forming a very long queue. For rotation schedules to work at secondary level, a regular and predictable supply is crucial, and the further downstream one moves along the main canal, the more risk and anxiety there is as regards sufficient water reaching the particular canal stretch for implementing the expected pattern of (unequal) water distribution at secondary level. There is thus a head-tail pattern at main canal level also. When too much water is abstracted by upstream secondary canals, farmers from downstream secondary canals mount pressure on the officials of their downstream division. To manage such pressures, the irrigation agency divisions have produced an adapted discharge table for the main canal. The discharge table specifies discharges (in $\mathrm{m}^{3} / \mathrm{sec}$ ) and water levels (in meters) at canal division boundaries. Given a particular discharge at the dam exit, the corresponding water levels at the head and tail of each division can be read off. The official discharge table is calculated on the basis of the localisation schedule ${ }^{e e}$ allocation pattern. This is, however, totally unrealistic in practice. In response the irrigation agency has internally designed an adapted, informal discharge table in which it has shifted the columns in such a way that more realistic corresponding discharges and water levels are given. This informal table serves as the institutional instrument for managing internal conflict and external pressure as regards water distribution along the main canal. It is largely an irrigation officials affair farmers influence canal management at this level only by lobbying and agitation, and efforts at manipulating the gate settings at the entry point of their own secondary canal. 
This is the accepted version of an article that will be published by Taylor and Francis in Journal of Peasant Studies. Please refer to the published version when citing, available at:

http://www.tandfonline.com/loi/fjps20\#.V5X4yfkrKUk

Accepted Version downloaded from SOAS Research Online: http://eprints.soas.ac.uk/22702/

\subsection{The social relations of unequal water distribution}

The rules at these three levels constitute the concretely existing „access relations" for irrigation water. The rules are „functional“ ${ }^{\text {e }}$ in the sense that they are instrumental in reproducing a particular pattern of water distribution. This is a highly unequal pattern in the Tungabhadra LBC case, hence their repeated (dramatic) contestation every irrigation season. In this sense, these rules, which effectively redefine the legal entitlements as embodied in the localisation schedule in a spatially and thereby socially skewed pattern, are „credible ${ }^{\text {ee }}$. They are actively mobilised by managers and users in conducting water distribution. ${ }^{16}$ The rule systems are coping strategies that reduce the transaction costs of water distribution, even when their being in a constant state of subversion and (re)negotiation makes the rules fragile. Their apparent relative endurance over time could be described, following Ho"s introduction to this issue, as the expression of a Progressive Disequilibrium. The endurance of rule systems that reproduce, in this case, inequality needs to be understood as the expression of and upheld by a particular power balance and social logic, which is summarised in Figure 1. This situation is similar to the one described by Ho on the Grazing Ban in China (see this volume). ${ }^{17}$

16 Note that in this case the „credibility“e of the actually existing rule system has no positive normative connotations (as the word"es synonyms like trustworthiness, standing, sincerity and believability may suggest). The use of the rule system is pragmatic - many water users are still worse off than they should be according to formal rules, and this is a feltinjustice.

17 It can also be noted that the coexistence of a formal, legal allocation plus set of rules, and the rules of actually existing access, do not constitute a case of „legal pluralism“e in the classical sense of two rule systems that are alternatively mobilised depending on situations and actors at hand. The formal, legal system is rarely called upon (anymore) for solving water distribution problems (though reproduced for other reasons), while actually existing access 
This is the accepted version of an article that will be published by Taylor and Francis in Journal of Peasant Studies. Please refer to the published version when citing, available at:

http://www.tandfonline.com/loi/fjps20\#.V5X4yfkrKUk

Accepted Version downloaded from SOAS Research Online: http://eprints.soas.ac.uk/22702/

\section{FIGURE 1 HERE}

Central in Figure 1 are the rich and middle peasants. They are the main appropriators of excess water, that is, intensive rice cultivators. ${ }^{18} \mathrm{I}$ have called them elite farmers above because they are also local leaders, for instance at the head of formal Water Users Associations (WUAs) and, practically more important, of informal farmer groups and networks, which lobby the irrigation agency for securing access to water. In the local expression these are the farmers that are „economically and politically sound"e. When irrigation water access becomes problematic in peakdemand periods, these farmers would exert pressure on the irrigation department officials (the formally responsible managers of the system), through a series of means, which sometimes results in (extra) water being supplied. When this does not yield sufficient result, the elite farmers use an indirect route to exert this pressure via the elected member of parliament of their constituency. In India"s constituency based democracy, elected rural politicians depend on the local elites that control the „vote banks ${ }^{\text {ee }}$ in their constituency. Elite farmers exchange electoral support against the politician ${ }^{\text {ee }}$ influence on the irrigation department as regards the provision of irrigation water. Politicians have such influence because they control the „market for public office ${ }^{e e}$, as seminally

relations are the dominant rule system, co-designed by government managers, irrigators and politicians.

18 This connection is partly recursive: farmers who happen to be in a location that allows excess appropriation of water can become rich and middle peasants over time because their relatively high income allows them to expand their holdings. However, already large/affluent farmers have also acquired land in favourable locations. On the water distribution related land market, and the phenomenon of land lease and purchase by inmigrating (rice) farmers, see Mollinga (2003, chapter 5). 
This is the accepted version of an article that will be published by Taylor and Francis in Journal of Peasant Studies. Please refer to the published version when citing, available at:

http://www.tandfonline.com/loi/fjps20\#.V5X4yfkrKUk

Accepted Version downloaded from SOAS Research Online: http://eprints.soas.ac.uk/22702/

described in Wade ${ }^{\text {ee }}$ (1982, 1985) analysis of the system of administrative and political corruption. Indian government officials are regularly transferred, and for securing or avoiding certain transfers, or sometimes for staying in position, government officials need to make payments to politicians. They source the funds for these payments primarily from the budget for the physical works (maintenance and construction) for the irrigation system they work in. The third set of relations that the elite farmers maintain are with the small and poor peasants in their area. Elite farmers also are major employers of local labour, and frequently act as local moneylenders, thus creating dependency relations with the group of small and poor peasants. These small and poor peasants have some limited leverage in this relationship as voters being mobilised as part of an elite „vote bank ${ }^{e e}$. To reproduce the political support that elite farmers require for the exertion of their leadership, they, among other things, share a part of the excess/extra water they secure with small and poor peasants. ${ }^{19}$ The agency of small and poor peasants depends, apart from the features of labour and credit markets, on competition between different elite sections; the irrigation department officials ${ }^{\text {ee }}$ room to manoeuvre similarly consist in the fact that there are a series of local elites located on different sections along the canal that are competing for water. The simplified structure presented here does thus not produce simple, linear social processes and outcomes, but structures a highly dynamic process of contestation.

19 This is one point at which the equity dimension of localisation is frequently discursively mobilised by elite farmers towards government officials and elected politicians. For a broader analysis of the populism of India"s 1970s and 1980s „,new farmers movements ", see Brass (1995); for Karnataka specifically see Nadkarni (1987). 
This is the accepted version of an article that will be published by Taylor and Francis in Journal of Peasant Studies. Please refer to the published version when citing, available at:

http://www.tandfonline.com/loi/fjps20\#.V5X4yfkrKUk

Accepted Version downloaded from SOAS Research Online: http://eprints.soas.ac.uk/22702/

\subsection{The role of water rights in unequal distribution in the Tungabhadra $L B C$}

Based on this description of actually existing water distribution practices in the

Tungabhadra LBC case, I offer two reflections that qualify the contribution of property rights analysis to the understanding of unequal water distribution.

A first reflection regards the rights and access notions. The presentation in the previous section shows that farmers ${ }^{\text {ee }}$ water use is shaped by a set of access relationsin the forms of rules at different canal levels. These rules have no direct connection with the entitlements as defined in the localisation schedule. In fact, they have emerged over time as a response to the impossibility to implement localisation "es allocation pattern. Localisation practically only exists as a normative principle, not as an operational tool. This situation confirms Ribot and Peluso ${ }^{e s}$ (2003) argument, for local natural resource use more generally, that apart from a theory of rights, a theory of access is required. The centrality of rules crafted „in process ${ }^{\text {ee }}$ plus the practical irrelevance of formally defined entitlements, illustrates, strongly, their point that distribution cannot be „read offe property rights, and that access relations need to be analysed in their own right. Thus, even when property rights would matter, they would not be the only thing that mattered given that ,access ${ }^{e e}$ needs to be looked at separately.

A second qualification of the purchase of property rights based analysis relates to the contextuality of rights. In the case study discussion above I have carefully avoided the „rights ${ }^{\text {ee }}$ word and spoken as much as possible about „entitlements ${ }^{\text {ee }}$ instead, notwithstanding the legal status of these entitlements. There has been a period in which the localisation-defined entitlements for Tungabhadra LBC farmers were actively treated as rights by irrigators, notably by those who could not realise their entitlement to water. In the 1970s and 1980s hundreds, if not thousands, of writ petitions were registered at the High Court of Karnataka submitted by farmers who did not receive 
This is the accepted version of an article that will be published by Taylor and Francis in Journal of Peasant Studies. Please refer to the published version when citing, available at:

http://www.tandfonline.com/loi/fjps20\#.V5X4yfkrKUk

Accepted Version downloaded from SOAS Research Online: http://eprints.soas.ac.uk/22702/

water as per the localisation schedule, with reference to the clauses in the Irrigation Act mentioned above. ${ }^{20}$ At policy level, discussion on a „law and order ${ }^{\mathrm{ee}}$ approach to the implementation of localisation continued till well into the 1970s (GOMYS/DOA 1968; GOKAR/PD 1976; CADA/TBP 1979). By the late 1980s, however, „tailenders ${ }^{\text {ee }}$ had lost their confidence in legal action as a feasible strategy for securing access to water, that is, no longer considered their entitlement as an enforceable right.

In Indian canal irrigation policy and academic discourse, entitlements to irrigation water are not generally referred to as „,water rights ${ }^{e e}$, notwithstanding their legal anchoring. These entitlements are treated more as allocations prescribed and to be implemented by the state administration rather than as (enforceable) rights of individual farmers. Government, after all, has claimed the overall ownership of water, to be used in the public interest. This reflects the developmental state $\mathrm{s}$ ambition of the first decades after independence, but Upadhyay (2009) also proposes a deeper dimension of this. In the context of a conflict about water stored behind the Hirakud dam in the state of Orissa, which the government (being the owner of the dam and the water), sought to partially re-allocate to industry and where farmers claimed that the waters really belong to „the people of western Orissa ${ }^{e e}$, he states the following.

„If questions in law and jurisprudence are never seriously raised inpopular movements and protests, they are equally (if not more so) ignored by the governments of the day. This is perhaps because raising the ownership question and investigating the state rights vis-à-vis the rights of the people in water means questioning entrenched beliefs, vested interests and altering power equations. This understanding strengthens the tendency of not invoking such questions or addressing them head on." (ibid., 143)

20 This was documented in fieldwork in 1991-92, when I looked up registered cases at the High Court and interviewed advocates involved in such cases (see Mollinga 2003, 72-75). 
This is the accepted version of an article that will be published by Taylor and Francis in Journal of Peasant Studies. Please refer to the published version when citing, available at:

http://www.tandfonline.com/loi/fjps20\#.V5X4yfkrKUk

Accepted Version downloaded from SOAS Research Online: http://eprints.soas.ac.uk/22702/

In the footnote attached to this section he further states:

„The author feels that the ownership question in water has never been seriously addressed by policymakers and jurists despite the continuing claims and counterclaims on the part of the State and the people." (ibid., fn. 22,143)

Though formal water law is clear about the state control, this claim is only partly felt to be legitimate by the people (irrigated farmers in the case example). This can be understood as an instance of the long-standing problematic relationship of Indian states with the populace in terms of legitimacy and accountability, including the independent democratic state. Kaviraj (1997) argues that the Western form of political democracy that India adopted after independence was an elite project implanted on Indian society „from the top ${ }^{\text {ee }}$, which „meant that a problem of intelligibility of the political institutions of the state remained at the heart of the Indian democratic system $^{\text {ee }}$ (ibid., 232). A structure has been reproduced in which the state is exterior to local social dynamics, and is seen as a whimsical tyrant with which one enters into relations of patronage and which one tries to control or influence in part for onees own benefit, but never considers as one"s own (for more discussion, see Mollinga 2010). Entitlements are treated as privileges accorded by government rather than as rights of those entitled.

Clear and unambiguous legal text cannot resolve this situation. To the contrary, this situation to an important extent annuls the force of law, while tending to produce a highly polarised form of (water) politics (Mollinga 2010). Property rights, even when clearly defined and legally enshrined, have no force by themselves: the force of legal concepts and definitions is always contextual. While at some point farmers believed that the localisation-based entitlements provided strong legal claims, and government pursued, or at least seriously discussed, a law and order approach to its implementation, this faith and conviction has disappeared in the realities of Indiaes competitivepopulist 
This is the accepted version of an article that will be published by Taylor and Francis in Journal of Peasant Studies. Please refer to the published version when citing, available at:

http://www.tandfonline.com/loi/fjps20\#.V5X4yfkrKUk

Accepted Version downloaded from SOAS Research Online: http://eprints.soas.ac.uk/22702/

politics and actually existing relations between the administrative and political arms of the state, as summarised in Figure $1 .^{21}$

These two points, the independent status of access relations and the contextuality of law, already provide good reasons to be sceptical about explanations of unequal water distribution and other ,performance problems ${ }^{\text {ee }}$ of canal irrigation that start from an economic theory-based primacy of property rights. The next section takes a more detailed look at economic theory-inspired discussion of canal irrigation (reform) in India and elsewhere.

\section{Economic theory and canal irrigation (reform)}

This section discusses whether or not the strengthening of the (individual private) property status of water might be instrumental in addressing the ,performance problems ${ }^{e e}$ of canal irrigation.

\section{1 'Marketisation' inspired canal irrigation reform}

The post-1990 period is not the first time that Indian canal irrigation has seen attempts to introduce (neo)liberal logics in its management. For the colonial period attempts at volumetric supply and contractual water delivery in north India have been reported by Stone $(1984,180-3)$. They were abandoned in 1870 . The mid- $19^{\text {th }}$ century saw an attempt at private irrigation investment through the Madras Irrigation and Canal

21 The equity dimension of localisation continues to be mobilised discursively in thepolitical sphere, the localisation schedule continues to be used to calculate formal canal release schedules at the start of the irrigation seasons, and administrative documentation of its violation is routinely produced. Localisation thus primarily has symbolic purchasearguably of declining strength. 
This is the accepted version of an article that will be published by Taylor and Francis in Journal of Peasant Studies. Please refer to the published version when citing, available at:

http://www.tandfonline.com/loi/fjps20\#.V5X4yfkrKUk

Accepted Version downloaded from SOAS Research Online: http://eprints.soas.ac.uk/22702/

Company (MICC) (Atchi Reddy 1990), which ended with the Crown taking over the company. Early $20^{\text {th }}$ century saw a concerted attempt in the Bombay Presidency, present Maharashtra, which failed to establish the volumetric pricing of water (Bolding et al. 1995).

Since the early 1990s, a decade sometimes described as the age of „,market triumphalismee (Peet and Watts 1993), there has been a new surge of advocacy of „marketisation ${ }^{\text {ee22 }}$ of/in canal irrigation. Globally, the strongest version of this perspective was an argument for the introduction of „tradable water rights ${ }^{\mathrm{ee}}$ to solve both allocation and efficiency problems in water resources management, including canal irrigation (Rosegrant and Binswanger 1994). This is a perspective that posits the need for clear and unencumbered private property in water, to allow market mechanisms to do their optimisation work: allocation of water to the use with highest economic benefits, and the constitution of incentives for efficient water use. However, there is only one southern country in which this discourse was taken to its full practical conclusion, namely Chile. In Chile, allocative and use efficiency did not result from the introduction of tradable water rights, as has been documented by Bauer (1997, 2004, 2015). Efforts to expand the Chilean approach to other countries in Latin America met with great resistance, with the emblematic Cochabamba „water war"e as the best known example (Nickson and Vargas 2002).

This strong articulation of „tradable water rights ${ }^{e e}$ has not made it to discursive and policy prominence in Indian canal irrigation. However, a general sense of the

22 I use the term „marketisation "e to (loosely) refer to the variety of approaches to canal irrigation reform that find their inspiration in economic theories focusing on thepositive allocative and efficiency work that private property based markets and market(-like) mechanisms can do. 
This is the accepted version of an article that will be published by Taylor and Francis in Journal of Peasant Studies. Please refer to the published version when citing, available at:

http://www.tandfonline.com/loi/fjps20\#.V5X4yfkrKUk

Accepted Version downloaded from SOAS Research Online: http://eprints.soas.ac.uk/22702/

desirability of „more market ${ }^{\text {ec }}$ in irrigation is present in Indian irrigation academic and policy writing. The clearest exponent of this is perhaps Saleth (1996) - a resource economist then based at the Institute of Economic Growth, Delhi. He claims that “[t]he economic rationality and urgency for a water institution based on a legally-based and farmer-managed water rights system are indeed very clear and compelling” (p.271) and argues that the "institutional significance of the rights system for sustainable development emerges from the fact that it is one of those rare policy instruments that can simultaneously address three critical goals of sustainable development, i.e., ecological security, economic efficiency, and social equity” (p.272-3). This is based on the premise that " $[\mathrm{t}]$ he present institutions governing water use do not allow the emergence of a mechanism to effectively capture and transmit either the scarcity value or the use value of water to the farmers" (p.235) and that "[i]n order for the water rights system to perform its economic function (...) [f]irst, water rights should be defined on a private basis. And, second, they should transferable, or, at least amenable to a rental system.” (p.243) In policy-related writing similar thinking is found, though usually less focused on „,water rights ${ }^{\text {ee }}$ as such, but on the introduction of market(-like) mechanisms and private sector participation more broadly, and often with a call on international experience (cf. Mohanty and Gupta 2002; Shah et al. 2004). ${ }^{23}$

India has seen only weak translations of such mainstream economics inspired discourse into canal irrigation reform policy. The post 1990 attempts at Participatory

\footnotetext{
${ }^{23}$ The 2030 Water Resources Group (WRG), established by the IFC (International Finance Corporation ) in partnership with the World Economic Forum, private companies and development agencies, is a global carrier of this discourse that is also active in India (see 2030 Water Resources Group 2012).
} 
This is the accepted version of an article that will be published by Taylor and Francis in Journal of Peasant Studies. Please refer to the published version when citing, available at:

http://www.tandfonline.com/loi/fjps20\#.V5X4yfkrKUk

Accepted Version downloaded from SOAS Research Online: http://eprints.soas.ac.uk/22702/

Irrigation Management (PIM) are only a half-hearted attempt at the introduction of water pricing, and mainly focus on organising water users into associations, and rehabilitating canal infrastructure. ${ }^{24}$ Partly as a result of global discourse and policy leverage, some Indian government Irrigation Departments have been recast as companies (Nigams), Karnataka and Gujarat being two examples. However, these continue to function as government agencies in practice, and are far removed from the concept of „self-financing irrigation bureaucracies ${ }^{\text {ee }}$ (Merrey, 1996), that is, irrigation bureaucracies functioning like corporate entities having to balance their budgets, notably through fee collection from water users.

Times may be changing, however, also in this respect. A recent development in Indian irrigation policy is a shift towards the introduction of regulatory authorities for the water sector, as part of broader liberalisation policy, and following such introduction in the electricity sector. The state of Maharashtra has advanced furthest in this regard through the creation and functioning of the Maharashtra Water Resources Regulatory Authority (MWRRA). The approach is being expanded to the national scale. Part of the MWRRA mandate is to define individual water rights, also for agricultural water use. This explicit use of the „water right ${ }^{\text {ee }}$ notion is a novelty in the Indian context. (Wagle et

\footnotetext{
${ }^{24}$ Interestingly, the global policy concept of IMT (Irrigation Management Transfer) (cf.
} Vermillion, 1997), which has a much stronger „marketisation“e emphasis than PIM (Participatory Irrigation Management), has not gained currency in Indian irrigation scholarship and policy discourse, except in some globally funded research efforts (Brewer et al. 1999). The most thoughtful and balanced statement on issues of pricing in India irrigation remains Vaidyanathan (1992). 
This is the accepted version of an article that will be published by Taylor and Francis in Journal of Peasant Studies. Please refer to the published version when citing, available at:

http://www.tandfonline.com/loi/fjps20\#.V5X4yfkrKUk

Accepted Version downloaded from SOAS Research Online: http://eprints.soas.ac.uk/22702/

al. 2012; Warghade and Wagle 2013). The actual definition of individual water rights for agricultural water use does, however, not seem to have started so far.

A more concrete form of policy change is renewed interest in the commodification of canal irrigation. ${ }^{25}$ This does not express primarily through,,watere as an object of commodification, but in increasing private sector involvement in the deployment of „modern ${ }^{\text {ee }}$ water delivery technology, notably micro-irrigation(drip, sprinkler). This comprises kits for individual farmers, but also the construction of new micro-irrigation based irrigation systems, and units within systems, by private companies. This is combined with (ideas of) agribusiness forms of cash crop cultivation (vegetables, sugarcane) and marketing. ${ }^{26}$ Not very much exists on the ground so far, and what exists seems to experience considerable operational problems, but there clearly is a strong government-supported thrust in this direction. ${ }^{27}$

Notwithstanding little ,,marketisation ${ }^{e e}$ practice in Indian canal irrigation , it is relevant to critique the reasoning underpinning market/private property inspired irrigation reform thinking as that discourse remains present and is gaining prominence in policy debates. These policy debates are not only ideologically inspired, but also address concrete challenges in and for canal irrigation, notably 1) the continuingly acute

${ }^{25}$ This paragraph is based on fieldwork in Karnataka, Andhra Pradesh and Gujarat in2015.

${ }^{26}$ Cf. the brochure Proposed Scheme. Drip Irrigation for Sugarcane in Karnataka. A revolutionary initiative published by the Government of Karnataka, Department of Water Resources, Major and Medium Irrigation (n.d.).

${ }^{27}$ The Gujarat Green Revolution Company (GGRC) established by the Government of Gujarat to promote micro-irrigation, among other things, is an example (www.ggrc.co.in). 
This is the accepted version of an article that will be published by Taylor and Francis in Journal of Peasant Studies. Please refer to the published version when citing, available at:

http://www.tandfonline.com/loi/fjps20\#.V5X4yfkrKUk

Accepted Version downloaded from SOAS Research Online: http://eprints.soas.ac.uk/22702/

„performance problems ${ }^{\text {ee }}$ in canal irrigated agriculture, and 2) the increasing pressure to allocate water „out of agriculture ${ }^{e e}$ for urban and industrial use.

\subsection{Critique of market and private property focused thinking on canal irrigation}

This subsection critiques market/private property inspired thinking on canal irrigation

(reform). In general, three types of critique of market/private property inspired thinking on canal irrigation (reform) can be distinguished. Two of these are of general nature, not specific for but applicable to canal irrigation.

(1) The economic theory underlying ,marketisation "e oriented thinking is fundamentally flawed: private property based markets cannot do the allocative and efficiency work that economic theory wants it to do.

(2) The neo-institutionalist economics perspective, like other disciplinary perspectives, is reductionist: as a partial, one-dimensional perspective it fails to capture the causal complexity of irrigation situations; the implicitly or explicitly claimed primacy of a single causal factor is unhelpful for both analysis and design of realistic reform approaches.

The first two points I treat briefly as the arguments supporting them are well known in the critical literature on markets and neoliberalism. The third critique addresses the specificity of canal irrigation, is perhaps less well known, and I discuss it in some more detail.

(3) Canal irrigation does not allow private property/market based arrangements to work (well) because of the specific technical and institutional features of canal irrigation systems and their management. 
This is the accepted version of an article that will be published by Taylor and Francis in Journal of Peasant Studies. Please refer to the published version when citing, available at:

http://www.tandfonline.com/loi/fjps20\#.V5X4yfkrKUk

Accepted Version downloaded from SOAS Research Online: http://eprints.soas.ac.uk/22702/

First and second critique: how markets really work

Mainstream economics is seen by its critics to have an idealised view of how markets and the private property arrangements that underpin them (could) work (cf. Mackintosh 1990, White 1993). In such critiques markets and property (and related phenomena like prices) are regarded as specific instances of the generic notion of institutions, and as relational objects, expressing and representing specific configurations of social relations of power. Examples include Granovetter ${ }^{\text {ec }}$ analysis of the „embedded ${ }^{\text {ee }}$ nature of markets (Granovetter 1985), and for property rights specifically the notion that natural resource rights are „,bundles of rights ${ }^{e e}$, as developed in theories of legalpluralism (Benda Beckmann and van der Velde 1992), and, as already discussed above, the insight that to capture resource management dynamics a theory of access is required in addition to a theory of rights (Ribot and Peluso 2003).

A specific variant of this kind of insight/critique in the Indian context is the analysis of „interlocked markets ${ }^{e e}$ showing how different types of market transactions are linked, producing power effects (Sarap 1991). Debate on groundwater access is largely about the existence of such interlockedness and its effects (see Prakash (2005) on the relationship between sharecropping and access to water in Gujarat). In the Tungabhadra LBC case the explanation of unequal water distribution also has a strong element of interlocking: local water distribution is interlocked with credit and labour markets, system level water distribution is interlocked with the market for public office. The specific form of these linkages helps to explain (unequal) outcomes.

What such „fundamental ${ }^{\text {ee }}$ critiques of mainstream economics ${ }^{\text {ee }}$ understanding of market, property and price have given us is a conceptual apparatus for a much more refined understanding of how the institutions of property, market and price „really work $^{\text {ee }}$, in a relational, multidimensional, embedded and evolutionary way. 
This is the accepted version of an article that will be published by Taylor and Francis in Journal of Peasant Studies. Please refer to the published version when citing, available at:

http://www.tandfonline.com/loi/fjps20\#.V5X4yfkrKUk

Accepted Version downloaded from SOAS Research Online: http://eprints.soas.ac.uk/22702/

\section{Third critique: water as an , uncooperative commodity"}

The third critique argues that the „resilience ${ }^{e e}$ of canal irrigation management practices to „marketisation ${ }^{\text {ee }}$, partly lies in the specific material and institutional characteristics of large-scale canal irrigation systems and the water that flows through them. In the context of urban water supply, Bakker (2003) has characterised water as „,an uncooperative commodity ${ }^{e e}$. This characterisation can also be applied to canalirrigation. Credit goes to Moore (1989) for providing the first detailed argument on this, before the „marketisation" hype of the early 1990s. He argues that “it is rarely practicable to apply scarcity pricing rigorously because of the economic and technical infeasibility of volumetric water pricing in most Third World irrigation schemes.” (ibid., 1733)

„The reasons for the infeasibility of volumetric water pricing lie in the interaction of a number of physical and economic characteristics of water and of LSGFISs [large scale gravity flow irrigation systems]. (...) water is an unusually mobile physical commodity. It has a high predisposition to flow, to seep vertically and horizontally through soils, to evaporate and transpire. On surface irrigationsystems one has also to consider the way in which rainfall adds to aggregate supplies in a variable and unpredictable fashion and the correspondingly unpredictable losses (...) Domestic water and electricity supply systems are (...) very misleading models for LSGFISs. (...) „, (ibid., 1738)

Both demand and supply of water have a considerable degree of variability and unpredictability for reasons beyond the control of managers and users. Furthermore, given the size and fluid nature of water it is practically very difficult to accurately police water distribution in large scale irrigation even under the best of institutional circumstances. Though irrigation systems can in theory be made to function like piped water supply systems in which each individual user can independently open the tap and 
This is the accepted version of an article that will be published by Taylor and Francis in Journal of Peasant Studies. Please refer to the published version when citing, available at:

http://www.tandfonline.com/loi/fjps20\#.V5X4yfkrKUk

Accepted Version downloaded from SOAS Research Online: http://eprints.soas.ac.uk/22702/

pay for volume used, this is practically almost unimaginable for a large-scale canal irrigation system populated with many tens of thousands of smallholders, and economically prohibitive, that is too expensive. Even when this could/would be realised at the level of groups of farmers taking water from a single „tap ${ }^{e e}$ at will, this would still not amount to the existence of a ,water market ${ }^{\text {ee }}$. A model in which farmers can purchase water from different providers using the same supply grid (as in electricity privatisation) is highly unrealistic. The basin-level interconnectedness of water cycles and flows subverts any model in which there are independent private suppliers/producers of water catering to a set of customers. Given these challenges, even water pricing (without a water market) is difficult to implement as it requires a strong managerial framework for delivery and for monitoring - the weakness of which is precisely the reason to introduce pricing and markets in the mainstream economic perspective! Molle and Berkoffers (2007) review of the practices of water pricing confirms that there are virtually no examples in canal irrigation where prices and markets do the work that mainstream economic theory wants them to do. To conclude, the specific material and institutional features of canal irrigation make the „marketisation "e of water management and governance a challenge. $^{28}$

${ }^{28}$ This ,uncooperative commodity“e argument should not be essentialised. For example, in England and Wales efforts are ongoing to push further the incomplete process of marketization of urban water supply, which has been argued to have stalled because of the ,uncooperative ee nature of water, through new interventions in the institutional context (cf. Walker 2014). The point is that a lot of „embedding "work may be required to make markets work more as envisaged in theory. The feasibility of such efforts depends on characteristics 
This is the accepted version of an article that will be published by Taylor and Francis in Journal of Peasant Studies. Please refer to the published version when citing, available at:

\section{Conclusion: beyond property rights in water}

The discussion above has shown that there is no lack of clarity in the formal definition of property rights in land, state ownership of water, and irrigators ${ }^{\mathrm{ee}}$ legal entitlements to water in Indian canal irrigation, as illustrated by the Tungabhadra Left Bank Canal south Indian irrigation system. Farmers ${ }^{\text {ee }}$ private property rights in land are not disputed; the state severall ownership of water resources is legally clear, and as far as water management within canal irrigation systems is concerned, not contested ${ }^{29}$; the water entitlements of individual farmers are legally and clearly enshrined in the localisation schedule. It is thus difficult to argue that insecurity in property rights lies at the basis of the „performance problems ${ }^{e e}$ of south Indian, and by implication other, canal irrigation systems. The discussion above vindicates Ribot and Peluso"es argument that in addition to a theory of property, a theory of access is required. At the same time, it also demonstrates the problem of the neo-liberal focus on institutional form instead of function. The institutional dimension of system performance is about the intricacies of access relations rather than property relations. Secondly, it has been shown that law (in this case, legal definitions of entitlements) is only as forceful as the context allows it to be, and that „claritye does not constitute force by itself. In addition it has been shown that notions like property, market and price have to be ,pluralised ${ }^{\text {eee }}$ : theirmultiple dimensions need to be considered, in contrast to the more singular understanding of

of both the existing cultural political economy and the resources management system, neither of which is, however, immutable..

29 The Indian state"s ownership claim on water resources has been increasingly contested in past decades in the case of new diversions. 
This is the accepted version of an article that will be published by Taylor and Francis in Journal of Peasant Studies. Please refer to the published version when citing, available at:

http://www.tandfonline.com/loi/fjps20\#.V5X4yfkrKUk

Accepted Version downloaded from SOAS Research Online: http://eprints.soas.ac.uk/22702/

these concepts in mainstream economic (and, for that matter, in quite a bit of heterodox political economy) theory. Such conceptual extension yields a vocabulary that allows a richer and more refined analysis of the social relations of irrigation water management, as illustrated with the case example. Another addition has been that a consideration of the specific material and institutional features of canal irrigation matter for the type of institutional arrangements for water distribution that are possible - causing significant constraints to ,marketisation ${ }^{\text {ee }}$.

It is also not easy to see how a strengthening of the legal status of individual water entitlements to explicit water rights might do much to make water distribution less unequal. Given the weakness of the legal and administrative enforcement system, the contrary is more easily imaginable. For instance, when entitlements would become tradable use rights, a further accumulation of water could possibly ensue through the same interlocked dependencies of water distribution with credit and employment that were described above. In a positive interpretation such tradable use rights might, in contrast, become a mechanism for tail-enders to receive at least some compensation for the excess upstream appropriation. However, the same systemic weakness would militate against the effective making of payment claims. I conclude that upsetting the function and credibility of existing rules systems, no matter how pragmatic they may be, and notwithstanding their role in the reproduction of unequal distribution, should be treated with care as institutions arise in an endogenous manner. This is why the intentional design of institutions as propagated in the neo-liberal paradigm should be viewed with suspicion. Changes in the formal property status of water alone are unlikely to affect existing access patterns in canal irrigation, unless accompanied by, or pa rt of, changes of power balances in the governance and management structure of canal irrigation. 
This is the accepted version of an article that will be published by Taylor and Francis in Journal of Peasant Studies. Please refer to the published version when citing, available at:

http://www.tandfonline.com/loi/fjps20\#.V5X4yfkrKUk

Accepted Version downloaded from SOAS Research Online: http://eprints.soas.ac.uk/22702/

\section{Acknowledgement}

A draft of this paper was presented at the annual European Association for Evolutionary

Political Economy conference held in Cyprus, November 2014, session "Why insecure property rights should not concern us: importance of institutional function and credibility”.

\section{References}

2030 Water Resources Group. 2012. The Water Resources Group. Background, Impact and the Way Forward. Briefing report prepared for the World Economic Forum Annual Meeting 2012 in Davos-Klosters, Switzerland. 26 January 2012.

Atchi Reddy, M. 1990. Travails of an irrigation canal company in South India, 1857-1882. Economic and Political Weekly 25, no. 12: 619-28 .

Aziz, A., and S. Krishna. 1997. Land reforms in India. Volume 4: Karnataka - promises kept and missed. Land reforms in India series. New Delhi: Sage.

Bakker, K.J. 2003. An uncooperative commodity: privatizing water in England and Wales. Oxford: Oxford University Press.

Bauer, Carl J. 1997. Bringing water markets down to earth: the political economy of water rights in Chile, 1976-95. World Development 25, no.5: 639-56.

Bauer, Carl J. 2004. Siren song: Chilean water law as a model for international reform. Washington DC: Resources for the Future.

Bauer, Carl. J. 2015. The law of the pendulum? Water conflicts and governance in Chile since reform in 2005. Water Alternatives 8, no.2: 147-72.

Benda-Beckmann, F. von, and M. van der Velde, eds. 1992. Law as a resource in agrarian struggles. Wageningsche Sociologische Studies 33. Wageningen:Agricultural University.

Bolding, Alex, Peter P. Mollinga, and Kees van Straaten. 1995. Modules for modernisation: colonial irrigation in India and the technological dimension of agrarian change. Journal of Development Studies 31, no.6: 805-44.

Brass, Tom, ed. 1995. New farmers' movements in India. Essex and Portland: Frank Cass. 
This is the accepted version of an article that will be published by Taylor and Francis in Journal of Peasant Studies. Please refer to the published version when citing, available at:

http://www.tandfonline.com/loi/fjps20\#.V5X4yfkrKUk

Accepted Version downloaded from SOAS Research Online: http://eprints.soas.ac.uk/22702/

Brewer, J., S. Kollavalli, A.H. Kalro, G. Naik, S. Ramnarayan, K.V. Raju and R.

Sakthivadivel. 1999. Irrigation management transfer in India. Policies, processes and performance. New Delhi: Oxford \& IBH Publishing.

CADA/TBP (Command Area Development Authority/Tungabhadra Project). 1979.

Report of the Tungabhadra Project Ryots Grievances Committee. Munirabad.

Chambers, Robert. 1988. Managing canal irrigation: practical analysis from South Asia. New Delhi and Calcutta: Oxford \& IBH Publishing Co.

Cullet, P. 2009. Water law, poverty and development: water law reforms in India. Oxford: Oxford University Press.

Dhawan, B.D. 1988. Irrigation in India's agricultural development: productivity, stability, equity. New Delhi: Sage.

Dhawan, B.D. 1989. Enhancing production through crop pattern changes. Artha Vijnana 31, no. 2: 153-75.

Dubash, N.K.2002. Tubewell capitalism, groundwater development and agrarian change in Gujarat. New Delhi: Oxford University Press.

Famine Commission. 1880. Report of the Indian Famine Commission 1880-1885. Part

I-III. New Delhi. Agricole Publishing Academy, 1989.

Famine Commission. 1881. East India (Report of Famine Commission). Appendix V. Irrigation as a protection against famine. London: George Edward Eyre and William Spottiswood.

Famine Commission. 1898. Report of the Indian Famine Commission 1898. New Delhi: Agricole Publishing Academy, 1989.

Gadgil, M., and R. Guha. 1992. This fissured land: an ecological history of India. New Delhi: Oxford University Press.

GOI/KWDT (Government of India/Krishna Water Disputes Tribunal). 1973. The report of the Krishna Water Disputes Tribunal with the decision. Volume I. Volume II. Volume III. New Delhi .

GOI/MOIP (Government of India/Ministry of Irrigation and Power). 1972. Report of the Irrigation Commission. Volume I. New Delhi.

GOKAR/PD (Government of Karnataka/Planning Department). 1976. Report on reexamination of cropping pattern under T.B.P. Left Bank Canal by the technical committee. Tungabhadra Project. 
This is the accepted version of an article that will be published by Taylor and Francis in Journal of Peasant Studies. Please refer to the published version when citing, available at:

http://www.tandfonline.com/loi/fjps20\#.V5X4yfkrKUk

Accepted Version downloaded from SOAS Research Online: http://eprints.soas.ac.uk/22702/

GOMYS/DOA (Government of Mysore/Department of Agriculture). 1968. Report of the expert committee on the development of light irrigation on the Left Bank area of the Tungabhadra Project 1965. Bangalore.

Granovetter, Mark S. 1985. Economic action and social structure: the problem of embeddedness. American Journal of Sociology 91: 481-510

Hart, Henry C. 1978. Anarchy, paternalism, or collective responsibility under the canals? Economic and Political Weekly 13, no. 51-52: A125-34.

Ho, Peter. 2014. The „credibility thesis “ and its application to property rights: (in)secure land tenure and social welfare in China. Land Use Policy 40, September: 13-27.

Ho, Peter. 2013. In defense of endogenous, spontaneously ordered development: the institutional structure of China ${ }^{e e}$ s rural urban property rights. Journal of Peasant Studies 40, no. 6: 1-32.

IIC (Indian Irrigation Commission). 1903. Report of the Indian Irrigation Commission 1901-1903. London: Her Majesty's Stationery Office.

Janakarajan, S. and Marcus Moench. 2006. Are wells a potential threat to farmers' wellbeing? Case of deteriorating groundwater irrigation in Tamil Nadu. Economic and Political Weekly 41, no. 37: 3977-87.

Jurriëns, Rien, and Peter P. Mollinga. 1996. Scarcity by design: protective irrigation in India and Pakistan. ICID Journal 45, no. 2: 31-53.

Kaviraj, Sudipta, 1997. The modern state in India. In Martin Doornbos, and Sudipta Kaviraj, eds. Dynamics of state formation. India and Europe compared, 225-50. New Delhi: Sage..

Lowdermilk, Max K. 1990. Irrigation, water control and anarchy. In R.K. Sampath, and Robert A. Young, eds. Social, economic, and institutional issues in Third World irrigation management, 155-74. Studies in Water Policy and Management No. 15. Boulder CO: Westview Press.

Mackintosh, Maureen. 1990. Abstract markets and real needs. In H. Bernstein, B. Crow, M. Mackintosh, and C.Martin, eds. The food question: profits versus people?, 43-53. London: Earthscan Publications.

Malhotra, S.P. 1982. The warabandi system and its infrastructure. Publication No. 157. , New Delhi: Central Board of Irrigation and Power. 
This is the accepted version of an article that will be published by Taylor and Francis in Journal of Peasant Studies. Please refer to the published version when citing, available at:

http://www.tandfonline.com/loi/fjps20\#.V5X4yfkrKUk

Accepted Version downloaded from SOAS Research Online: http://eprints.soas.ac.uk/22702/

Merrey, Douglas J. 1996. Institutional design principles for accountability in large irrigation systems. Research Report 8. Colombo: International Irrigation Management Institute.

Mitra, Ashok K. 1986. Underutilisation revisited: surface irrigation in drought prone areas of western Maharashtra. Economic and Political Weekly 26, no. 17: 752-6.

Mohanty, Nirmal and Gupta, Shreekant. 2002. Water reforms through water markets: International experience and issues for India. In: Morris, Sebastian and Rajiv Shekhar (eds.) India infrastructure report 2002. Governance issues for commercialisation. New Delhi: Oxford University Press, pp.217-225,

Molle, Francois, and Jeremy Berkoff. 2007. Water pricing in irrigation: the lifetime of an idea. In Francois Molle and Jeremy Berkoff, eds. Irrigation water pricing: the gap between theory and practice, 1-20. Oxfordshire, UK: CABI Publishers.

Mollinga, P.P. 2003. On the waterfront. Water distribution, technology and agrarian change in a South Indian canal irrigation system. Wageningen University Water Resources Series. Hyderabad: Orient Longman.

Mollinga, Peter P. 2010. The material conditions of a polarised discourse. Clamours and silences in critical analysis of agricultural water use in India. Journal of Agrarian Change 10, no.3: 414-36

Moore, Mick. 1989. The fruits and fallacies of neoliberalism: the case of irrigation policy. World Development 17, no. 11: 1733-50.

Nadkarni, M.V. 1987. Farmers' movements in India. Ahmedabad: Allied Publishers.

Narain, Vishal. 2003. Instiutions, technology and water control. Water Users Associations and irrigation management reform in two large-scale systems in India. Wageningen University Water Resources Series. Hyderabad: Orient Longman.

Nickson, Andrew, and Claudia Vargas. 2002. The limitations of water regulation: the failure of the Cochabamba concession in Bolivia. Bulletin of Latin American Research 21, no.1: 99-120.

Ostrom, Elinor. 1990. Governing the commons: The Eeolution of institutions for collective action. New York: Cambridge University Press. 
This is the accepted version of an article that will be published by Taylor and Francis in Journal of Peasant Studies.

Please refer to the published version when citing, available at:

http://www.tandfonline.com/loi/fjps20\#.V5X4yfkrKUk

Accepted Version downloaded from SOAS Research Online: http://eprints.soas.ac.uk/22702/

PC/GOI (Planning Commission/Government of India). 2013. Water. In Twelfth Five Year Plan (2012-2017). Faster, more Inclusive and sustainable growth. Volume 1, 144-89. New Delhi: Sage.

Peet, Richard, and Michael Watts. 1993. Introduction: development theory and environment in an age of market triumphalism. Economic Geography 69, no.3: 227-53

Prakash, Anjal. 2005. The dark zone: groundwater irrigation, politics and social power in North Gujarat. Wageningen University Water Resources Series. New Delhi: Orient Longman.

Rath, N., and A.K. Mitra. 1989. Economics of irrigation in water-scarce regions: study of Maharashtra. Artha Vijnana 31, no. 1: 1-129.

Ribot, Jesse C. and Nancy Lee Peluso. 2003. A theory of access. Rural Sociology68, no.2: $153-181$.

Robb, Peter, ed. 1983. Rural India: land, power and society under British rule. London: Curzon Press.

Rosegrant, Mark W., and Hans P. Binswanger. 1994. Markets in tradable water rights: potential for efficiency gains in developing country water resource allocation. World Development 22, no.11: 1613-25.

Saleth, R. Maria. 1996. Water institutions in India: Economics, law and policy. Studies in Economic Development and Planning No.63. New Delhi: Commonwealth Publishers.

Sarap, Kailas. 1991. Interlinked agrarian markets in rural India. Institute of Economic Growth Studies in Economic Development and Planning No. 57. , New Delhi: Sage.

Shah, Tushaar. 2009. Taming the anarchy: groundwater governance in South Asia. Colombo: International Water Management Institute.

Shah, Tushaar, Christopher Scott and Stephanie Buechler. 2004. Water sector reforms in Mexico: Lessons for India's new water policy. Economic and Political Weekly. 39, no.4: 361-370.

Shah, Tushaar and K. Vengama Raju. 1988. Ground water markets and small farmer development. Economic and Political Weekly 33, no.13: A23-A28. 
This is the accepted version of an article that will be published by Taylor and Francis in Journal of Peasant Studies. Please refer to the published version when citing, available at:

http://www.tandfonline.com/loi/fjps20\#.V5X4yfkrKUk

Accepted Version downloaded from SOAS Research Online: http://eprints.soas.ac.uk/22702/

Stone, Ian. 1984. Canal irrigation in British India: perspectives on technological change in a peasant economy. Cambridge South Asian Studies No.29. Cambridge: Cambridge University Press.

Suhardiman, Diana, and Peter P. Mollinga. 2012. Correlations, causes and the logic of obscuration: donor shaping of dominant narratives in Indonesiaes irrigation development. Journal of Development Studies 48, no.7: 923-38

Upadhyay, Videh. 2009 .The ownership of water in Indian laws. In Ramaswamy Iyer, ed. Water and the laws in India, 134-48. New Delhi: Sage.

Vaidyanathan, A. (Chair) (1992) Report of the Committee on Pricing of Irrigation Water. Planning Commission, Government of India, New Delhi. Reproduced in the Indian Journal of Agricultural Economics 49(1), 107-133, Jan-March 1994.

Vermillion, D. L. 1997. Impacts of irrigation management transfer: a review of the evidence. Research Report 11. Colombo: IIMI.

Wade, Robert. 1976. Rationing water: principle and practice in South India. [mimeograph] ODI Workshop on Choices in Irrigation Management 27 September-1 October 1976. Paper C.4. Sussex: Institute of Development Studies.

Wade, Robert. 1982. The system of administrative and political corruption: canal irrigation in South India. Journal of Development Studies 18, no. 3: 287-328.

Wade, Robert. 1985. The market for public office: why the Indian state is not better at development. World Development 13, no. 4: 467-97.

Wagle, S., S. Warghade, and M. Sathe. 2012. Exploiting policy obscurity for legalising water grabbing in the era of economic reform: the case of Maharashtra, India. Water Alternatives 5, no.2: 412-30.

Walker, Gareth. 2014. Water scarcity in England and Wales as a failure of meta)governance. Water Alternatives 7, no.2: 388-413

Wallach, Bret. 1985. British irrigation works in India's Krishna basin. Journal of Historical Geography 11, no. 2: 155-73.

Warghade, Sachin, and Subodh Wagle. 2013. Independent regulatory bodies in the water sector: issues and prospects. Paper presented in the felicitation conference „Water sector in India: A critical engagement ${ }^{\text {ee }}$ in honour of Prof. Ramaswamy Iyer, 25-27 November 2013, New Delhi. 
This is the accepted version of an article that will be published by Taylor and Francis in Journal of Peasant Studies. Please refer to the published version when citing, available at:

http://www.tandfonline.com/loi/fjps20\#.V5X4yfkrKUk

Accepted Version downloaded from SOAS Research Online: http://eprints.soas.ac.uk/22702/

Whitcombe, Elizabeth. 1972. Agrarian conditions in northern India. Vol. I. The United

Provinces under British rule, 1860-1900. Berkeley: University of California Press.

White, Gordon. 1993. Towards a political analysis of markets. IDS Bulletin 24.3.

Sussex: Institute of Development Studies. 
This is the accepted version of an article that will be published by Taylor and Francis in Journal of Peasant Studies. Please refer to the published version when citing, available at:

http://www.tandfonline.com/loi/fjps20\#.V5X4yfkrKUk

Accepted Version downloaded from SOAS Research Online: http://eprints.soas.ac.uk/22702/

Figure 1: The social relations of unequal water distribution in the Tungabhadra Left

Bank Canal (Mollinga 2003, 360) 